Radmila D Čurčić

Ljiljana Z Miletić ${ }^{2}$ Miroslav J Bjegović ${ }^{3}$
JEL: M1, M14, D12

DOI: 10.5937/industrija1-10104

UDC: 005.35

659.113.25

Original Scientific Paper

\title{
Contrasting of CSR Strategies self-presentations and consumers expectations in Serbia
}

Article history:

Received: 27 December 2015

Sent for revision: 20 January 2016

Received in revised form: 9 February 2016

Accepted: 12 February 2016

Available online: 1 April 2016

\begin{abstract}
Corporate social responsibility (CSR), as a widely accepted approach is often applied by the companies not only to create a social impact but also as a powerful tool to create the image of the company among customers and increase its visibility. In order to contrast the CSR concepts of leading companies in Serbia as a country in a long-lasting post-socialist transition with the consumers' expectations, search of web-based selfpresentations of leading companies in Serbia and questionnaire among consumers were used in present research. Obtained results point out that self-presentation of CSR programs by the leading companies in Serbia is in collision with consumers' expectations in respect to both, presented CSR motives and emphasized CSR activities. Companies are mainly emphasizing performance-driven motives for CSR, while consumers rate higher the motives related to stakeholders and value-based motives. Environment protection is the only activity recognized with similar importance by the companies and by the consumers. Consumers' expectations are the highest in respect to stakeholders-related CSR including consumers, employees and suppliers, while the companies rarely emphasize these aspects of CSR. Oppositely, support for social issues and donations employed very frequently by the companies do not meet high consumers' expectations.
\end{abstract}

Keywords: CSR, strategy, consumers, expectations, comparison

\footnotetext{
${ }^{1}$ University Union-Nikola Tesla, Faculty for industrial business management, Belgrade

${ }^{2}$ University Educons, Faculty for project and innovation management, Belgrade, ljilianam962@gmail.com

3 University Educons, Faculty for project and innovation management, Belgrade
} 
Čurčić D.R. et al.: Contrasting of CSR Strategies self-presentations and consumers...

\section{Uporedna analiza prezentacija strategije KDO i očekivanja potrošača u Srbiji}

Apstrakt: Korporativnu društvenu odgovornost (KDO) kao široko prihvaćen pristup kompanije primenjuju ne samo da bi ostvarile uticaj na društvo već vrlo često i kao moćno sredstvo formiranja imidža među potrošačima i postizanja bolje vidljivosti na tržištu. Kako bi se uporedili koncepti KDO vodećih kompanija u Srbiji kao zemlji u dugoj post socijalističkoj tranziciji, sa očekivanjima potrošača, izvršena je pretraga prezentacija vodećih kompanija na internetu i izvršeno istraživanje među potrošačima na bazi upitnika. Dobijeni rezultati ukazuju da su prezentacije programa KDO vodećih kompanija u Srbiji u koliziji sa očekivanjima potrošača, kako u pogledu motiva za realizaciju aktivnosti $K D O$, tako i u pogledu samih aktivnosti. Kompanije uglavnom ističu motive vezane za uspeh kompanije dok potrošači više vrednuju očekivanja vezana za motive usmerene na interesne grupe, kao $i$ motive vezane za društvene vrednosti. Zaštita životne okoline je jedina aktivnost kojoj visok značaj pridaju $i$ potrošači $i$ kompanije. Očekivanja potrošača su najviša kada su u pitanju aktivnosti usmerene na same potrošače, zaposlene, pa i dobavljače dok kompanije retko ističu ove aspekte $K D O$. Nasuprot tome, podrška socijalnim pitanjima i donacije kao česti elementi KDO uključeni od strane kompanija ne nailaze na visoka očekivanja potrošača.

Ključne reči: KDO, strategija, potrošači, očekivanja, upoređenje

\section{Introduction}

Nowadays, corporate social responsibility (CSR) becomes an inevitable part of contemporary corporate development.

Corporate social responsibility of a business implies the simultaneous fulfillment of economic, legal, ethical and philanthropic responsibilities of the company. Socially responsible company should at the same time strive to make the profit, obey the law, be ethical, and be a good corporate citizen (Carroll, 1991). Among researchers the definition of CSR given by Campbell (2007) is widely accepted, defining CSR as the actions taken by a company that are intended to further social welfare beyond the direct economic, technical, and legal interests of the company.

Corporate social responsibility has nowadays become a mainstream, with huge spendings on CSR activities by companies worldwide (Vlachos et al., 2009). CSR activities are used to address consumers' social concerns, create a favorable corporate image, and develop a positive relationship with consumers and other stakeholders. It became evident that companies 
Čurčić D.R. et al.: Contrasting of CSR Strategies self-presentations and consumers...

practice CSR not only for the benefits of society but as much also to increase visibility as to create social impact, and invest heavily not only in good actions but also in communicating them (Luo and Bhattacharya 2006).

Corporate web sites were proven to be important communication channels used by the companies to present their involvement in CSR because they target a variety of publics and because their content is defined by the company and is not dictated by any requirement or government regulations (Maignan and Ralston, 2002).

However, empirical evidence for market outcome of CSR is still inconclusive, but the idea that strategic adoption of CSR could lead to financial rewards in the long run is in general accepted among shareholders and investors (Lee, 2008). Success and survival of the companies is affected by various stakeholders such as shareholders, employees, governments and customers and the difference between the social and economic goals of a corporation are becoming narrower.

The studies treating consumers' perceptions of corporate motives and consumers' expectations and responses came into the focus of numerous research activities worldwide (Barone et al., 2007). Despite increasing research efforts investigating the effects of CSR on consumers' attitudes, existent research does not explain why consumers respond differently to companies that operate in the same industry and support similar CSR activities. However, it was proven that the suspicion of the consumers that the company's true motive for the CSR activity is only to improve its image might even result in negative image among consumers and thwarting the company's efforts (Yoon et al., 2006).

The effects of different types of cause-related marketing on consumer responses has been the issue in many research activities (Ross et al., 1992; Strahilevitz and Myers 1998; Barone et.al., 2000; Dean, 2004; Lafferty and Goldsmith, 2005) that point out that consumers' responses to CSR are more complex than once believed.

Regarding consumers' responses towards socially responsible companies, some researchers found that consumers generally have positive responses towards such companies (Pomering and Dolnicar, 2009; Podnar and Golob, 2007), whereas others uncovered that consumers are not interested in CSR (Carrigan and Attalla, 2001; Vaaland et al., 2008). Therefore, there is lack of consensus over consumer attitudes and consequent behavior towards CSR is evident (Karem Kolkailah et al., 2012).

Numerous research activities based on direct questionnaire reviews among consumers or on controlled experiments, in which potential consumers are confronted with various scenarios of CSR activities, mainly result in findings encouraging companies to be involved in CSR activities (Xiaoli, 2007). Yet, 
Čurčić D.R. et al.: Contrasting of CSR Strategies self-presentations and consumers...

general conclusions that would enable projection or quantification of assumed positive effects of different CSR activities among consumers are still inexistent and further investigations in this direction are needed.

Most of the research activities regarding the relations among CSR activities, concepts and strategies and consumers' preferences and behavior were conducted in developed countries (Brown and Dacin, 1997; Creyer et al., 1997; Maignan and Ferrell, 2000; Maignan, 2001; Uusitalo and Oksanen, 2004). Knowing that cultural dimensions play an important role in forming of consumer attitudes towards CSR (Williams and Zinkin, 2008) and the fact that CSR concept in developing countries and especially post-socialist countries had a different development path (Koleva et al., 2010, Stoian and Zaharia, 2012) the results from developed countries and market economies might not be directly applicable in different economic and social environments. For these reasons research on consumer perception of social responsibility in developing and especially post-socialist countries are still needed (Jamali, 2007; Arli et al., 2010) as a prerequisite for optimization of CSR concepts and their effects for both companies and all stakeholders including consumers.

The aim of present research is to collect, analyze and contrast the selfpresented CSR concepts of the leading companies in Serbia as a country in a long-lasting post-socialist transition with the consumer expectations regarding the motives of the companies to be involved in CSR and activities included in CSR programs.

\section{Materials and methods}

Conducted investigation consisted of two parts: internet search based survey of presentation of CSR motives and activities by the leading companies in Serbia and questionnaire based survey of consumers' expectations and attitudes related to the corporate social responsibility.

Internet search of presentation of CSR motives and activities was performed according to the methodology suggested by Maignan and Ralston (2002) with slight modifications. The companies involved in the research were randomly chosen from the list of the top 500 companies in Serbia (http://top500.nin.co.rs) in respect to the annual turnover. In order to ensure uniform participation of companies from different sectors, the companies from the list were divided by sectors prior to selection of the companies to be reviewed. The following sectors were predefined: agro-industry and food production, supplies and commodities production, services and trade, energy and fuel production and supply, financial sector and sector of infrastructure and large scale investments. From each sector 12 companies were chosen randomly from the list, resulting in 72 companies involved in total. In this way 
Čurčić D.R. et al.: Contrasting of CSR Strategies self-presentations and consumers...

involvement of main companies forming overall consumers' perception of CSR was ensured.

For each selected company the information regarding the position of CSR presentation, statement of CSR motives, involvement of different CSR activities in the presentation were collected from the self-presentations of CSR programs in official corporate web presentations. Motives were coded based on the statements provided by the companies as dominantly related to the performance of the company, dominantly related to stakeholders or dominantly related to moral and ethical values. Emphasized activities were categorized as related to environment protection, care for social issues, donations for issues of general interest, extended care for employees, fair treatment of suppliers, and fair treatment of consumers. In dependence of completeness of reporting and volume of activities they were coded as dominant or existent. Ownership of the company was also registered as the control variable.

The consumer's survey was conducted among consumers from the urban regions of Serbia (cities with above 50,000 inhabitants). In the questionnaire consumers were asked to rate their expectations from the companies on the Leakert scale (1-7). Expectations related to motives expected to be drivers for companies' CSR activities were rated for motives related to performance of the company, relation of the company with stakeholders and moral values related to social issues. Expectations related to CSR activities were rated for fair treatment of consumers, extended care for employees, environment protection, fair treatment of suppliers, participation in social issues supporting of events and donations not related to core business of the company. Consumers' sex, age, earnings level and attitude toward CSR were used as the control variables. In order to justify the approach of collection of information from corporate web presentations, frequency of utilization of communication channels from which consumers are informed about CSR activities was also rated by the respondents.

Frequency analysis and comparison of mean values of the obtained answers and testing of differences among the obtained distributions of answers were included in statistical data processing.

\section{Results and discusion}

The results of conducted research enable contrasting of self-presentation and consumers' expectations regarding the motives for realization of CSR programs and regarding the self-presentation of realized activities and consumers' expectations in respect to diverse CSR activities. 
Čurčić D.R. et al.: Contrasting of CSR Strategies self-presentations and consumers...

Prior to presentation of obtained results, in addition to arguments from academic literature justifying approach of collecting the information from the companies' self-presentation of CSR programs (Maignan and Ralston, 2002), the results of rating of the sources from which consumers are informed about CSR concepts and activities, obtained from the questionnaire, are presented in Table 1.

Obtained result, with companies' web pages positioned among first three sources for informing of consumers regarding CSR, confirm the validity of this information source as the one of the main instruments that participate in shaping of consumers' perception and attitudes regarding CSR programs implemented by the companies.

Table 1. Rating of sources from which consumers perceive to be informed about CSR

\begin{tabular}{lc}
\hline Sources of information & Ratings (1-7) \\
\hline Media & $4,93^{\mathrm{a}}$ \\
Web pages & $4,70^{\mathrm{ab}}$ \\
Advertisement & $4,64^{\mathrm{ab}}$ \\
Supported events & $4,53^{\mathrm{b}}$ \\
Reports and brochures & $4,17^{\mathrm{c}}$ \\
Word of mouth & $4,03^{\mathrm{c}}$ \\
\hline
\end{tabular}

*different letters indicate significant differences between the values, according to Duncan test at $p$ $\leq 0.05$.

Before the analysis of obtained insights from the CSR self-presentations by leading companies in Serbia, short review regarding existence of the selfpresentations, its positioning at the web pages and CSR reporting practices will be provided.

Out of the companies included in analysis of presentation of CSR activities at the web pages $57 \%$ companies emphasized their CSR activities in some way, while the remaining $43 \%$ did not mention CSR activities or CSR concept at all. The companies presenting their CSR activities mainly (75\%) positioned CSR as one of the core activities of the companies with direct links at the home page. Considerable differences were noticed in respect to CSR reporting between companies from private and public sector. In private sector the social responsibility of the company was presented by $62,3 \%$ of analyzed companies, while in the public sector only $36,8 \%$ companies involved some kind of presentation of their social responsibility in their web presentations.

However, deeper analysis of facts reported regarding CSR activities resulted in opposite findings. Only $25 \%$ of companies presenting themselves as socially responsible did present the actual CSR activities with documented 
Čurčić D.R. et al.: Contrasting of CSR Strategies self-presentations and consumers...

reports. Complete reports were provided by less than $15 \%$ of analyzed companies and the remaining companies provided links to individual projects or activities or a list of entities that were supported among the realized CSR activities. There were no significant differences between private and public sector regarding CSR reporting.

\subsection{Self-presentation of CSR motives vs. consumers' expectations}

In academic literature there are different approaches and diverse findings regarding the motives of the companies to apply the CSR concept, as well as attribution of these motives by the consumers (Ellen et al., 2006). However, distinguishing among motives related to contribution to overall performance of the company (strategic motives), motives related to fulfillment of stakeholders' expectations (stakeholder driven motives) and motives grounded in true corporate culture based commitment of the company (value based motives) is among frequently applied approaches (Ellen et al., 2006; Groza et al., 2011)

In the web page self-presentation of CSR, motives for involvement of companies in CSR programs are usually stated in few sentences at the main page presenting company as a responsible community member. Rarely, in the case of existence of documented CSR program, the official statement regarding CSR motives is provided. However, in some cases motives for involvement in CSR are not stated at all. Based on stated situation, in the cases of only $31 \%$ of analyzed companies (Fig.1) the statement of CSR motives could be identified, while for the rest of companies the CSR concept presentation did not exist $(43 \%)$ or the statement regarding motives of the company to take care of social responsibility were not stated $(26 \%)$.

Figure 1. Presentation of CSR motives and stated dominant motives for CSR by the companies in Serbia

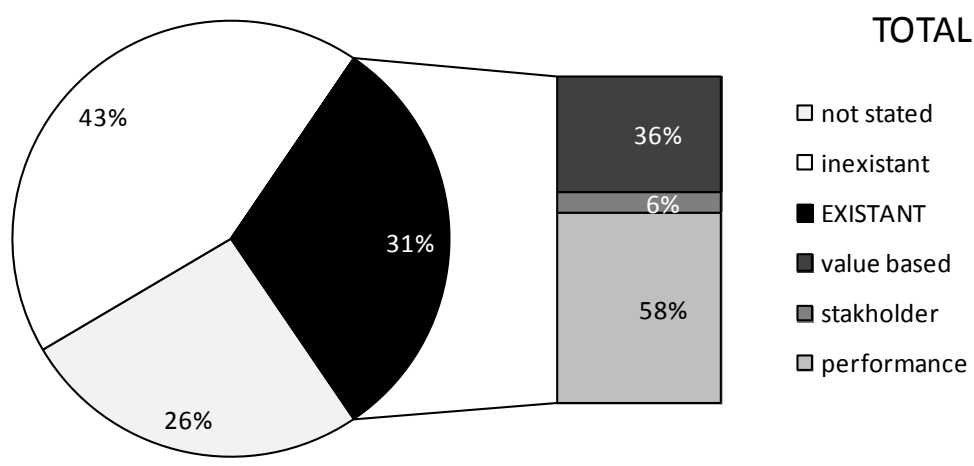


Čurčić D.R. et al.: Contrasting of CSR Strategies self-presentations and consumers...
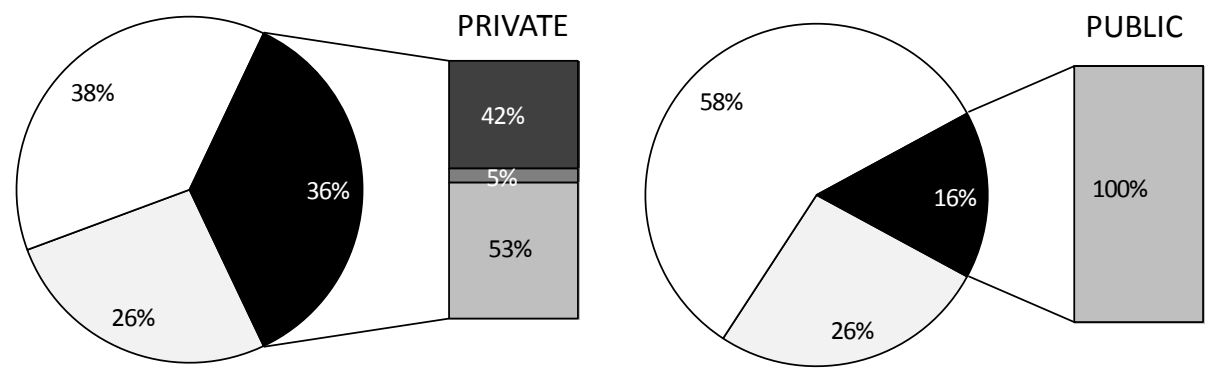

The companies dominantly stated that their involvement in CSR programs is motivated or connected to the excellence of their performance in general (58\%) (Fig.1). The frequency of the statement that CSR programs were motivated by value based motives grounded in the intrinsic belief of the company that it is morally obligated to care about social issues was much lower (36\%). Interesting observation is that the obligations and expectations related to the stakeholders, among which are also the consumers were almost inexistent among statements presenting the motives for CSR by the leading companies in Serbia. In very rare cases $(6 \%)$ respect and relations with suppliers were mentioned in CSR motives statements.

However, noticeable differences were observed concerning stated CSR motives in dependence of the company ownership (Fig.1) Among the companies from the public sector, the motives for CSR activities mainly were inexistent $(58 \%)$ or not stated $(26 \%)$, and the ones that emphasized their motives focused only at strategic motives related to the growth and success of the company $(100 \%)$. In the private sector the companies that provided statement about their motives to be involved in CSR activities were represented in higher share (36\%) than in the public sector. Among private companies that stated their motives for involvement in CSR strategic motives are also dominant $(53 \%)$. However, value based motives were emphasized also by considerable number of the companies (42\%). Emphasizing of stakeholders based motives was recorded only in private companies, but still very rare, by less than $5 \%$ of companies providing statements about CSR motives.

To summarize: leading companies in Serbia in self-presentations of their CSR programs mainly present performance related reasons as the motives for their involvement in CSR programs. Contrasting of this finding to consumers' expectations regarding the motives that should be behind the companies' CSR activities (Table 2) point out at the first inconsistency in this area. 
Čurčić D.R. et al.: Contrasting of CSR Strategies self-presentations and consumers...

Table 2. Comparison of average values of rating of consumers' expectation in respect to CSR motives and differences in distribution of answers among different groups of consumers

\begin{tabular}{|c|c|c|c|c|c|}
\hline \multirow[t]{2}{*}{ Expected motives } & \multirow[t]{2}{*}{ Average $^{\star \star}$} & \multirow[b]{2}{*}{ હ } & \multirow[b]{2}{*}{ ஓ্ণ } & \multirow[b]{2}{*}{ 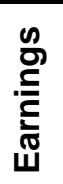 } & \multirow[b]{2}{*}{ 品 } \\
\hline & & & & & \\
\hline Value based motives & $5,65^{\mathrm{a}}$ & * & $\mathrm{ns}$ & ns & ns \\
\hline Stakeholders related motives & $5,64^{\mathrm{a}}$ & $\mathrm{ns}$ & ns & ns & ns \\
\hline Performance related motives & $5,21^{\mathrm{b}}$ & ns & ns & ns & ns \\
\hline
\end{tabular}

* differences significant with $p=0,05$ based on $x^{2}$ test of goodness of fit

${ }^{* *}$ different letters indicate significant differences between the values, according to Duncan test at $p \leq 0.05$.

Namely, value based and stakeholders' related motives were with statistical significance higher rated in comparison to performance related motives that are mainly emphasized by the companies. Based on the fact that no significant differences were found in distribution of obtained answers among observed consumers' groups, this finding is consistent for all consumers from urban population of Serbia. The only significant difference between the distributions of answers was recorded for male and female respondents in the case of value based motives. Insight in the mean values and distributions of answers of these rating point out that the mean values of the ratings were the same but that the male population was much more divided in the opinion, while the female population provided high frequency answers in wider range (Fig.2)

Figure 2. Differences in ratings of expectations for value based motives for CSR by male and female population of consumers in Serbia
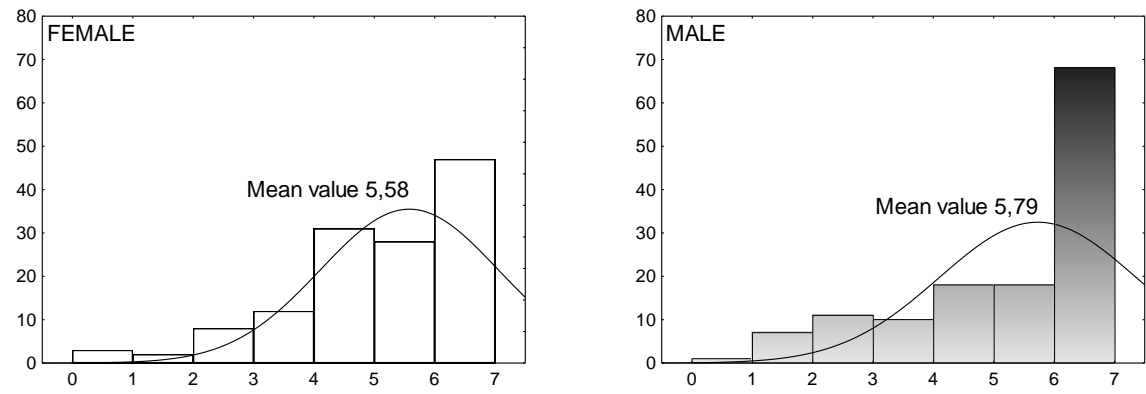
Čurčić D.R. et al.: Contrasting of CSR Strategies self-presentations and consumers...

According to the findings of Maignan and Ralston (2002) based on investigations conducted in France, Netherlands and UK, presentation of CSR as an activity enhancing the firm's success and survival is dominant practice among European companies, while the US companies mostly present introduction of CSR practices as an expression of their own organizational culture. On the other hand, in post-socialist countries, as stated by Koleva et al. (2010) on the basis of research conducted in Czech Republic, Slovakia, Bulgaria, and Romania, the hybrid CSR concept might have also developed in Serbia that is largely influenced by the exogenous CSR practices from foreign companies whose subsidiaries are the companies operating in Serbia. Direct introduction of such CSR practices and motives, without available or sought information about consumers' expectations resulted, quite possibly, in identified discrepancy between CSR motives self-presentation and consumers' expectations.

\subsection{Self-presentation of CSR activities vs. consumers' expectations}

Activities implemented by the companies in order to express their CSR motivations into practice can in general be categorized under three types targeting different issues: environment, stakeholders and social issues (Wood, 1991). In present research activities related to environment protection, stakeholders including consumers, suppliers and employees, as well as contributions to social issues and donations for activities of general interest were included.

Summarized findings regarding the self-presentation of conducted CSR activities by the companies in Serbia are provided in Fig.3.

Figure 3 - Self-presented CSR activities by the leading companies in Serbia with comparison of presented CSR activities by ownership

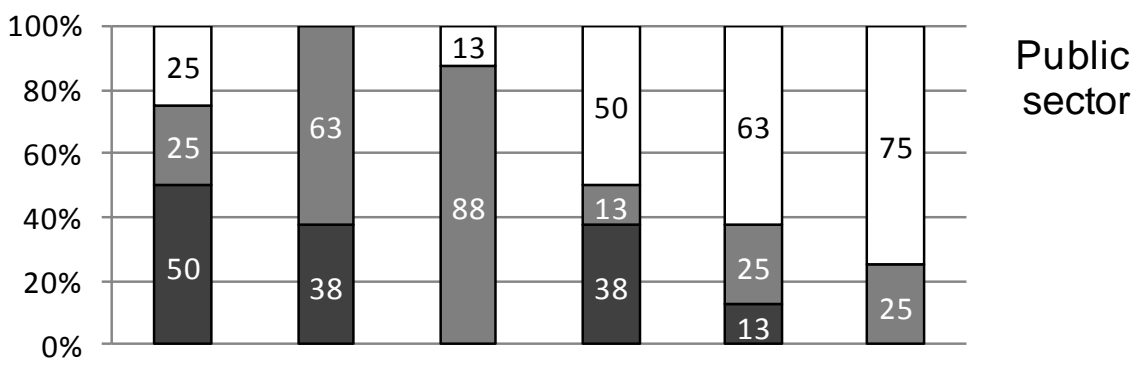


Čurčić D.R. et al.: Contrasting of CSR Strategies self-presentations and consumers...
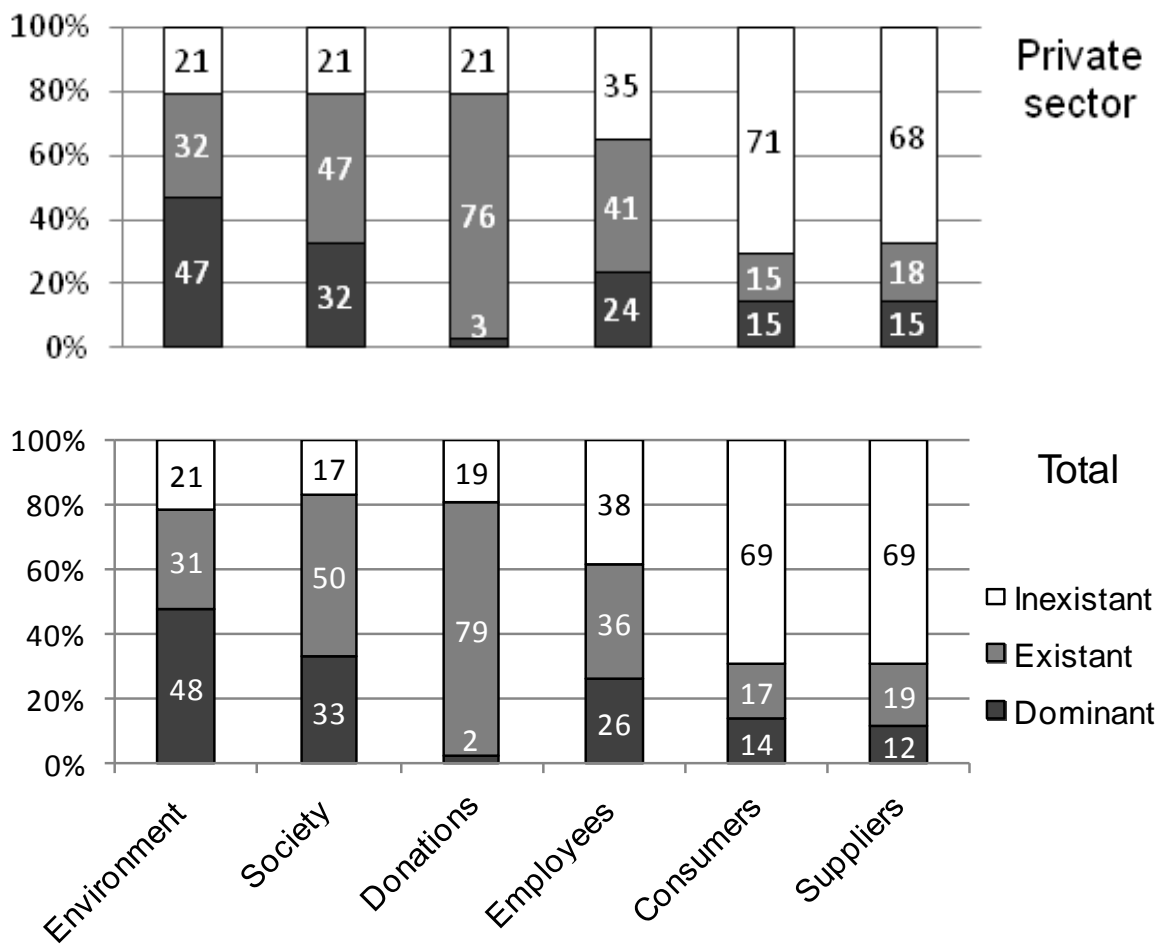

Only companies providing self-presentations of their CSR activities $(57 \%$ of total number of reviewed companies) are presented. The shares of companies presenting diverse CSR activities as dominant or as existent in their CSR programs are calculated based on total number of companies presenting themselves to be socially responsible. Findings are presented separately for companies with public and companies with private ownership and for total number of companies.

The dominant among activities presented as the act of company's social responsibility are the activities related to the protection of environment. Regardless of the ownership environment protection was presented as the activity of CSR by up to $80 \%$ of companies self-presenting themselves as socially responsible, with up to $50 \%$ of companies presenting environment protection area as one of the core activities with complete programs and reports about conducted and planned activities.

With quite similar frequency, companies present their contribution to the society in general through support of different projects of social development or donations in fields on common or local interest even if these fields are not 
Čurčić D.R. et al.: Contrasting of CSR Strategies self-presentations and consumers...

related in any way to company's core business. Support to social and local development is presented as dominant activity with programs and reports by approximately $30 \%$ of reviewed companies, while the donations are mainly only listed without detailed reports. Interesting observation is that all public companies presenting themselves as socially responsible present involvement in social development as part of their CSR.

Somewhat lower number of companies has some form of extended care for employees' program presented among CSR activities (50-60\% of companies having CSR activities presented at their web pages).

On the other hand, fair relations towards consumers and especially with the suppliers are presented as a part of CSR programs much rarely in comparison to emphasized issues of environment protection and society support and development with approximately only $30 \%$ of companies including these issues in the self-presentations of their CSR programs.

In contrast to the presented findings from self-presentations of CSR programs, the identified consumers' expectations regarding CSR (Table 3 ) are quite different.

Based on obtained findings the activity with outstanding expectations is fair treatment of consumers, which was the expectation with the highest rating regardless of the consumers' sex, age, earnings level or attitude towards CSR. This fact is obviously the guide mark for the companies to regard the care about their consumers as higher CSR priorities.

The second outstanding expectation is extended care for employees. This finding might be attributed to the expectations dating back into socialist period, in which care for employees was one of the priority of the companies and as such presents part of endogenous CSR in post-socialist countries (Koleva et al., 2010, Stoian and Zaharia 2012). However, findings from the review of the CSR self-presentations by the leading companies in Serbia point out that companies are only partly aligned in their CSR programs with the expectations in this field.

Finally, the third outstanding expectation regarding the CSR is the protection of the environment which is also the dominantly emphasized activity by the companies.

Very interesting observation is that the donations in the fields on common or local interest that are not related to company's core business are rated with the lowest expectations from the consumers. In contrast to this finding, based on the CSR self-presentations such activities are among the most frequently emphasized ones by the companies. The same situation can be stated for participation in social development and support to events of general interest that are not rated high among consumers' expectations. 
Čurčić D.R. et al.: Contrasting of CSR Strategies self-presentations and consumers...

Fair relation with suppliers, which is by the companies emphasized very rarely as a part of CSR is also by the consumers rated quite low but still higher than companies' involvement in social affairs and provision of diverse donations.

Table 3. Rating of consumers' expectations regarding CSR activities and differences in distribution of answers among different groups of consumers

\begin{tabular}{|c|c|c|c|c|c|}
\hline & Average $^{\star \star \star}$ & Ф્ & 六 & 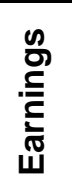 & 品 \\
\hline Fair treatment of consumers & $6,53^{\mathrm{a}}$ & ns & ns & $\mathrm{ns}$ & ns \\
\hline Extended care for employees & $6,26^{\mathrm{b}}$ & ns & ns & ** & * \\
\hline Environment protection & $6,10^{\mathrm{b}}$ & ns & ns & ns & ns \\
\hline Fair treatment of suppliers & $5,57^{\mathrm{C}}$ & ns & ns & ns & ns \\
\hline Participation in social issues & $5,51^{c}$ & ns & ns & ns & ns \\
\hline Supporting of events & $5,41^{c}$ & ns & ns & ns & ns \\
\hline Donations not related to core business & $5,17^{\mathrm{d}}$ & ns & ns & ns & ns \\
\hline
\end{tabular}

* differences significant with $p=0,05$ based on $x^{2}$ test of goodness of fit

** differences significant with $p=0,01$ based on $x^{2}$ test of goodness of fit

*** different letters indicate significant differences between the values, according to Duncan test at $p \leq 0.05$.

Differences in distribution of ratings obtained from the consumers were proven in the case of extended care of employees for consumers with different earning levels and with different attitudes towards CSR (Fig.4).

From presented results it is obvious that with more positive attitude towards CSR concept in general the expectations related to extended care about employees increase. Regarding the income levels, the highest expectations regarding the extended care for employees were recorded among consumers with medium incomes. The lowest expectations are among consumers with very high income levels and among consumers with very low income levels. 
Čurčić D.R. et al.: Contrasting of CSR Strategies self-presentations and consumers...

Figure 4. Differences between ratings of expectation of extended care for employees as part CSR depending on consumers' earning levels and CSR attitudes
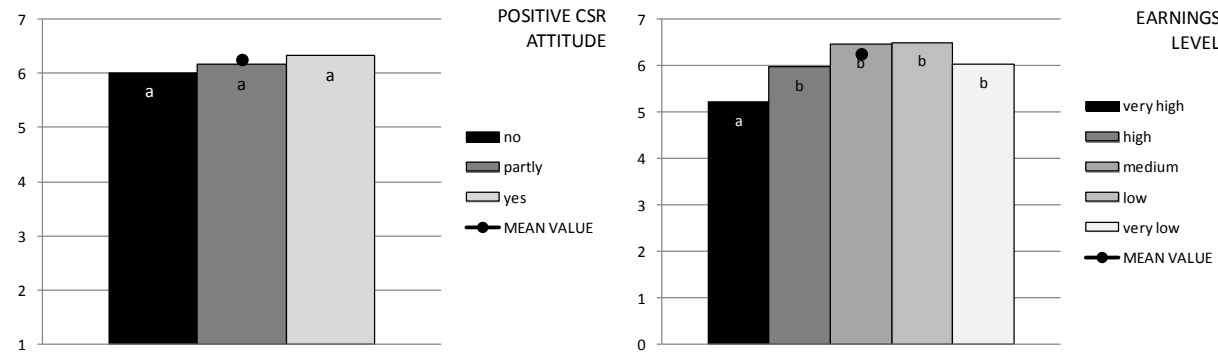

\section{Conclusions}

Self-presentation of CSR programs by the leading companies in Serbia is in collision with consumers' expectations in respect to presented CSR motives and emphasized CSR activities.

Companies mainly present performance-driven motives as the main reason to be involved in CSR activities, while the consumers expect primarily valuebased and stakeholders-related motives to be the driving factors for CSR.

Contributions to social issues and donations not related to company's core activities strongly emphasized in self-presentations of CSR by the companies are not highly expected activities by the consumers. In contrast, extended care for employees and especially for consumers are highly expected activities by the consumers, but the companies rarely emphasized it as part of CSR. Consumers and companies both agree on high importance of environment protection, as a part of CSR, but both consumers and companies do not give much attention to fair relation towards suppliers.

\section{References}

Arli, D. I. \& Lasmono H. K. (2010). Consumers' perception of corporate social responsibility in a developing country. International Journal of Consumer Studies, 34(1), 46-51.

Barone, M. J., Miyazaki, A. D. \& Taylor, K. A. (2000). The Influence of Cause-Related Marketing on Consumer Choice: Does One Good Turn Deserve Another? Journal of the Academy of Marketing Science, 28(2), 248-2 
Čurčić D.R. et al.: Contrasting of CSR Strategies self-presentations and consumers...

Barone, M. J., Norman, A. T. \& Miyazaki, A. D. (2007). Consumer response to retailer use of cause-related marketing: Is more fit better? Journal of Retailing, 83(4), 437-445

Brown, T. J. \& Dacin, P. A. (1997). The Company and the Product: Corporate Associations and Consumer Product Responses. Journal of Marketing, 61(1), p68-84

Campbell, J. L. (2007). Why would corporations behave in socially responsible ways? An institutional theory of corporate social responsibility. Academy of Management Review, 32(3), 946-967

Carrigan, M. \& Attalla, A. (2001) The myth of the ethical consumer - do ethics matter in purchase behaviour? Journal of Consumer Marketing, 18(7), 560-577

Carroll, A. B. (1991). The Pyramid of Corporate Social Responsibility: Toward the Moral Management of Organizational Stakeholders. Business Horizons, 34(4), $39-48$

Creyer, E. H., Ross, Jr. \& William, T. (1997). The influence of firm behavior on purchase intention: do consumers really care about business ethics? Journal of Consumer Marketing, 14(6), 419-432

Dean, D. H. (2004). Consumer reaction to negative publicity. Journal of Business Communication, 41(2), 192-211

Ellen, P., Webb, D. \& Mohr L. (2006). Building corporate associations: consumer attributions for corporate socially responsible programs. Journal of the Academy of Marketing Science, 34, 147-157.

Groza, M. D., Pronschinske, M. R. \& Walker, M. (2011). Perceived Organizational Motives and Consumer Responses to Proactive and Reactive CSR. Journal of Business Ethics, 102, 639-652

Jamali, D. (2007). The Case for Strategic Corporate Social Responsibility in Developing Countries. Business \& Society Review, 112(1), 1-27

Karem Kolkailah, S., Abou Aish, E. \& El-Bassiouny, N. (2012). The impact of corporate social responsibility initiatives on consumers' behavioural intentions in the Egyptian market. International Journal of Consumer Studies, 36(4), 369-384.

Koleva, P., Rodet-Kroichvili, N., David, P. \& Marasova, J. (2010). Is corporate social responsibility the privilege of developed market economies? Some evidence from Central and Eastern Europe. The international journal of human resource management, 21(2), 274-293.

Lafferty, B. A. \& Goldsmith, R. E. (2005). Cause--brand alliances: does the cause help the brand or does the brand help the cause? Journal of Business Research, $58(4), 423-429$

Lee, M-D.P. (2008). A review of the theories of corporate social responsibility: Its evolutionary path and the road ahead. International Journal of Management Reviews, 10(1), 53-73

Luo, X. \& Bhattacharya, C.B. (2006). Corporate Social Responsibility, Customer Satisfaction, and Market Value. Journal of Marketing, 70(4), 1-18

Maignan, I. \& Ferrell, O.C. (2000). Measuring Corporate Citizenship in Two Countries: The Case of the United States and France. Journal of Business Ethics, 23(3), 283-297

Maignan, I. \& Ralston, D.A. (2002). Corporate Social Responsibility in Europe and the US,: Insights from Businesses' Self-presentations. Journal of International Business Studies, 33(3), 497-514 
Čurčić D.R. et al.: Contrasting of CSR Strategies self-presentations and consumers...

Maignan, I. (2001). Consumers' perceptions of corporate social responsibilities: a cross-cultural comparison. Journal of Business Ethics, 30(1), 57-72

Podnar, K. \& Golob, U. (2007). CSR expectations: the focus of corporate marketing. Corporate Communications: An International Journal, 12, 326-340.

Pomering, A., Dolnicar, S. (2009). Assessing the prerequisite of successful CSR implementation: are consumer aware of CSR initiatives? Journal of Business Ethics, 85, 285-301.

Ross, III J. K., Patterson, L. T. \& Stutts, M. A. (1992). Consumer perceptions of organizations that use cause-related marketing. Journal of the Academy of Marketing Science, 20(1), 93-98

Stoian, C., Zaharia, R.M. (2012). CSR development in post-communist economies: employees' expectations regarding corporate socially responsible behaviour-the case of Romania. Business Ethics: A European Review, 21(4), 380-401.

Strahilevitz, M. \& Myers, J. G. (1998). Donations to Charity as Purchase Incentives: How Well They Work May Depend on What You Are Trying to Sell. Journal of Consumer Research, 24(4), 434-446

Uusitalo, O. \& Oksanen, R. (2004). Ethical consumerism: a view from Finland. International Journal of Consumer Studies. 28 (3), 214-221

Vaaland, T. I., Heide, M. and Grønhaug, K. (2008). Corporate social responsibility: investigating theory and research in the marketing context. European Journal of Marketing, 42 (9/10), 927-953

Vlachos, P., Tsamakos, A., Vrechopoulos, A. \& Avramidis, P. (2009). Corporate social responsibility: attributions, loyalty, and the mediating role of trust. Journal of the Academy of Marketing Science, 37, 170-180.

Williams, G. \& Zinkin, J. (2008). The effect of culture on consumers' willingness to punish irresponsible corporate behaviour: applying Hofstede's typology to the punishment aspect of corporate social responsibility. Business Ethics: A European Review, 17(2), 210-226

Wood D. (1991) Corporate Social Performance Revisited. Academy of Management Review. 16(4), 691-718.

Xiaoli, N. (2007). Social Distance, Framing, and Judgment: A Construal Level Perspective. Human Communication Research, 33 (4), 489-514

Yoon, Y., Gürhan-Canli, Z. \& Schwarz N. (2006). The Effect of Corporate Social Responsibility (CSR) Activities on Companies With Bad Reputations. Journal of Consumer Psychology (Lawrence Erlbaum Associates), 16 (4), 377-390. 